10.53116/pgaflr.2018.1.5

\title{
Impact of the Principle of Proportionality in Tax Law on the Jurisprudence of the Court of Justice of the European Union and the Supreme Administrative Court in Poland
}

\author{
Artur Mudrecki*
}

\begin{abstract}
* Artur Mudrecki, Professor at the Department of Financial and Tax Law, Kozminski University and a judge of the Supreme Administrative Court in Poland, Head of the Tax Law Department in the Judicial Decisions Bureau of the Supreme Administrative Court. He is also a member of the Fiscal Association Polish Branch and the International Association Centre for Information and Organization of Research on Public Finances and Tax Law of the Countries of Central and Eastern Europe - Association at the Białystok University, European Association of Tax Law Professors, Faculty of Law and the Financial Law Association AURES in Opole. He specialises in tax law and is the author of over 100 publications, mainly on tax law. Particularly noteworthy is his monograph Due Process in Tax Proceedings. (e-mail: amudrecki@kozminski.edu.pl)
\end{abstract}

\begin{abstract}
The principle of proportionality in tax law as an EU and constitutional standard may play an important role in the interpretation of tax law. The principle of proportionality is associated with moderation of the activities of public authorities and minimization of their interference in the sphere of rights and freedoms. The principle of proportionality is also called the principle of commensurability, moderation, and adequacy. The article analyses the impact of the proportionality principle in tax law on the case law of the Court of Justice of the European Union. The case law of the Polish Supreme Administrative Court uses the principle of proportionality when interpreting tax law, and the judgments of the Court of Justice of the European Union and the Polish Constitutional Tribunal have a significant impact on the jurisprudence of administrative courts in Poland.

Keywords: principles of law; the principle of proportionality; Court of Justice of the European Union; jurisprudence; the case law of the Constitutional Tribunal; the case law of the Supreme Administrative Court; Poland
\end{abstract}

\section{Introduction}

The objective of the article is to attempt at answering the question of what role is played by the principle of proportionality in tax law, with particular focus on the case law of the Court of Justice of the European Union (CJEU) and municipal courts in Poland.

This paper will offer answers to two fundamental questions:

1. Does the Court of Justice of the European Union, in tax cases, employ the analysed European standard, and are Polish solutions compliant with this European standard?

2. Does the case law of the Polish Supreme Administrative Court, in its interpretation of tax law provisions, employ the principle of proportionality, and 
do judgements of the Court of Justice of the European Union and Polish Constitutional Tribunal exert significant impact on the case law of administrative courts in Poland?

The principle of proportionality is an important standard in taxpayer rights protection and is associated with moderation of the activities of public authorities and minimization of their interference in the sphere of rights and freedoms. The principle of proportionality is also called the principle of commensurability, moderation, and adequacy (L. Etel, P. Pietrasz, Niekompletność świadczeń o przeznaczeniu oleju opatowego a zastosowanie sankcji podatkowej, o której mowa $w$ art. 89 ust. 16 ustawy o podatku akcyzowym [Incompleteness of declarations on the use of fuel oil and the imposition of the tax sanction provided for in Art. 89 (16) of the Value Added Tax Act], ZNSA, no. 2(41)/2012, p. 27). Furthermore, the principle of proportionality is linked with observation of the criteria of usefulness, necessity, and the weighing up of particular values.

The addressees of the principle of proportionality are:

1) the legislative authority

2) the executive authority

3) the judiciary

With consideration to the scope of the research set out in the article, the object of assessment will be observance of the principle of proportionality by the judiciary, id est by courts and tribunals.

\section{The Principle of Proportionality in the Normative Sense}

The principle of proportionality can be understood as a normative, doctrinal principle. It exerts significant influence on interpretation of legal provisions performed by tribunals and courts. The principle of proportionality in tax law is one of the most important general principles of European law. It should also be stated that the indicated standard is anchored in the Constitution of Poland. It impacts the interpretation applied by the Polish Supreme Administrative Court (SAC) in tax cases; that court applies an EU-friendly and constitutionally consistent interpretation.

In the normative sense, the legal basis of the principle of proportionality jest Art. 3b (3 and 4), incorporated into the Treaty on European Union and Treaty Establishing the European Community by the Lisbon Treaty, replacing Art. 5 ( 4 and 5) of the Treaty on European Union.

Under the principle of proportionality, the content and form of Union action shall not exceed what is necessary to achieve the objectives of the Treaties. The principle serves as criterion for evaluating the activities of EU institutions and is the basis for assessing actions taken by the member states (M. Bącal, in M. Militz, D. Dominik-Ogińska, M. Bącal, T. Siennicki, Zasady prawa unijnego [Principles of EU Law], Warsaw 2013, pp. 145146). 
Under the adopted solutions and under the principle of subsidiarity, in areas which do not fall within its exclusive competence, the Union shall act only if and in so far as the objectives of the proposed action cannot be sufficiently achieved by the Member States, either at central level or at regional and local level, but can rather, by reason of the scale or effects of the proposed action, be better achieved at Union level. The institutions of the Union shall apply the principle of subsidiarity as laid down in the Protocol on the application of the principles of subsidiarity and proportionality. As we can see, in this case the principle of proportionality is associated with the principle of subsidiarity. In order for these principles to be more than words on paper, the aforementioned Protocol also sets out mechanisms designed to ensure observance of the principle of proportionality. In particular, national Parliaments ensure compliance with the principle of subsidiarity in accordance with the procedure set out in that Protocol (Art. 3b[3]). Under the principle of proportionality, the content and form of Union action shall not exceed what is necessary to achieve the objectives of the Treaties. The institutions of the Union shall apply the principle of proportionality as laid down in the Protocol on the application of the principles of subsidiarity and proportionality (Art. 3b[4]).

The Protocol holds that each institution shall ensure constant respect for the principles of subsidiarity and proportionality set out in Article $3 b$ of the Treaty on European Union (Art. 1 Protocol). The Commission shall forward its draft legislative acts and its amended drafts to national Parliaments at the same time as to the Union legislator. The European Parliament shall forward its draft legislative acts and its amended drafts to national Parliaments (Art. 4 Protocol).

The Court of Justice of the European Union plays an important role in respect of adherence to the principles of proportionality and subsidiarity. It is competent to rule on cases concerning violations by a legislative act of the principle of subsidiarity brought by Member States in accordance with the provisions of Article 230 Treaty on the Functioning of the European Union (TfEU) or presented by them pursuant to their legal regimes in the name of a national parliament or chamber thereof. Under the rules set out in that same article, applications may be brought by the Committee of the Regions (CoR) in respect of legislative acts whose adoption requires consultation under the TfEU (Art. 8 Protocol). In addition, the Commission presents each year to the European Council, the European Parliament, the Council, and national Parliaments a report on application of Article 3b TEU. This annual report is also presented to the Economic and Social Committee and the Committee of the Regions (Art. 9 Protocol).

In addition, the principle of proportionality is present in the highest legal act in effect in Poland, the Constitution. Under Art. 31 (3) of the 1997 Constitution (OJ L no. 78, item 483 as amended), any limitation upon the exercise of constitutional freedoms and rights may be imposed only by statute, and only when necessary in a democratic state for the protection of its security or public order, or to protect the natural environment, health or public morals, or the freedoms and rights of other persons. Such limitations shall not violate the essence of freedoms and rights. This regulation also applies in tax law. 


\section{Impact of the Principle of Proportionality on the Case Law of the Court of Justice of the European Union}

Member States of the European Union are obliged to carry out timely and correct implementation (transposition) of EU regulations. The subject literature emphasizes that implementation as a whole is composed of: 1. normative implementation, 2. administrative implementation, and 3. judicial implementation. Judicial implementation refers to the role of municipal courts as EU courts applying principles of EU law and imposing sanctions for violations or non-application of EU law by individual entities (A. Kunkiel-Kryńska, Metody harmonizacji prawa konsumenckiego w Unii Europejskiej i ich wptyw na procesy implementacyjne w panistwach cztonkowskich [Methods of Harmonization of Consumer Law in the European Union and their Impact on Implementation Processes in Member States], Warsaw 2013, p. 89).

Recognition by the CJEU that judicial application of the law is an element of national implementation of a Directive makes it possible to: 1. grant courts the competence to assess whether a State has properly implemented European law, 2. achieve in the judicial application of law the objectives of EU law, including of Directives (principle of effectiveness of EU law), 3. interpretation of municipal law consistent with EU law, 4. uniform application of EU law in all Member States (see judgment of CJEU of 10 April 1984 in case C 14/83, Sabine von Colson and Elisabeth Kamann versus Land Nordrhein-Westfalen, and of 9 December 2003 in C-129/00, Commission versus the Republic of Italy).

In the judgment of the SAC of 12 June 2013 (I FSK 146/13) it is indicated that European Law provides a clear division of competences concerning interpretation and application of European law. The CJEU is the court competent to rule on binding interpretation and validity of acts of European Union law, while municipal courts as European courts are charged with the duty of applying those provisions and their interpretation in individual cases. Application of provisions of EU law by municipal courts encompasses inter alia the duty to apply those provisions and their interpretation in individual cases, as well as the duty to ensure the full effectiveness of provisions of EU law and non-application of provisions of municipal law that are in conflict with it (principle of primacy). An unambiguous and precise response by the CJEU concerning interpretation of EU law in practice determines the content of the judgement by a municipal court in a given case, and even in the absence of express regulation of the issue, in fact has binding force' (SAC judgment of 19 September 2008, I GSK 1038/07, Central Repository of Administrative Court Judgments - CRACJ).

Pursuant to Art. 260 TfEU, if the Court of Justice of the European Union finds that a Member State has failed to fulfil an obligation under the Treaties, the State shall be required to take the necessary measures to comply with the judgment of the Court. If the Commission considers that the Member State concerned has not taken the necessary measures to comply with the judgment of the Court, it may bring the case before the Court after giving that State the opportunity to submit its observations. It shall specify the amount of the lump sum or penalty payment to be paid by the Member State concerned which it considers appropriate in the circumstances (see CJEU judgment of 22 June 2016 
in C-557/14, European Commission vs Portuguese Republic [non-compliance with CJEU judgment of 7 May 2009 in case C-530/07, European Commission vs Portuguese Republic] and of 4 June 2009 in case C-568/07, Commission of the European Communities vs Hellenic Republic (non-compliance with CJEU verdict of 21 April 2005 in case C-140/03, Commission of the European Communities vs Hellenic Republic).

Here we should cite one such ruling by the CJEU. In its judgment C-241/11 of 25 June 2013, the CJEU imposed a lump sum payment on the Czech Republic of EUR 250,000 for failure to implement measures in a timely manner ensuring implementation of CJEU verdict C-343/08 of 14 January 2010. In assessing the seriousness of the infringement, the CJEU indicated that the absence in that country of a second pillar in its pension system, as well as the fact that institutions for occupational retirement provision are prohibited from establishing themselves in its territory, late compliance, by that Member State, with the judgment in Commission v. Czech Republic had a limited effect on the internal market for occupational retirement provision, which Directive 2003/41, according to recitals 1, 6 and 8 in the preamble thereto, seeks to establish, and, therefore, on private and public interests (para 53). In particular, the complete transposition of Directive 2003/41 is intended principally to inform interested persons in the event that, as the Court observed in paragraph 51 of the judgment in Commission v. Czech Republic, the national retirement pension system develops in that regard (para 54).

The CJEU, in deciding whether interpretation of the provision of the Act performed by the Supreme Court of the Czech Republic constitutes legislation, emphasized that assessment of the scope of municipal legislative, executive, and administrative provisions must be performed with heed to the interpretation given by municipal courts (verdict C-382/92 of 8 June 1994, Commission vs United Kingdom). In consequence, the notion of "legislation of a member state" is understood by the CJEU as also encompassing interpretation of a provision of municipal legislation performed by a national Supreme Court (CJEU judgment of 15 March 2018 in case C-431/16, Instituto Nacional de la Seguridad Social (INSS), Tesoreria General de la Seguridad Social (TGSS) vs José Blanc Markus).

From the above said we may conclude that the Court of Justice of the European Union plays a primary role in the interpretation of EU law. Because of the principle of primacy in the application of EU law and effectiveness of that law, municipal courts must respect verdicts of the CJEU. If they fail to adhere to the interpretation indicated by the CJEU, they may be at risk of a fine, as in the case of the Czech Republic, whose Supreme Court ignored a judgment of the CJEU.

The Union principle of proportionality has been invoked quite frequently in tax law cases decided by the CJEU. The Court has reviewed compliance of national solutions with the principle of proportionality. This test has frequently led to decisions of benefit to taxpayers, for example, that a given legislative solution adopted in an EU Member State violated that principle. However, there is also a collection of rulings by the CJEU holding that this principle was not infringed.

For reasons of space, the article only gives some examples of CJEU judgments concerning the research problem undertaken, with particular attention to rulings that have been handed down in Polish cases. 
In its judgment C-418/14 of 2 June 2016 in ROZ-ŚWIT Zakład ProdukcyjnoHandlowo-Usługowy Henryk Ciurko, Adam Pawłowski spółka jawna vs Dyrektor Izby Celnej we Wrocławiu, the CJEU held that Directive 2003/96/EC of 27 October 2003 restructuring the Community framework for the taxation of energy products and electricity and the principle of proportionality must be interpreted as:

- not precluding national legislation under which sellers of heating fuel are required to submit, within a prescribed time limit, a monthly list of statements from purchasers that the products purchased are for heating purposes, and

- precluding national legislation under which, if a list of statements from purchasers is not submitted within a prescribed time limit, the excise duty applicable for motor fuels is applied to the heating fuel sold, even though it has been found that the intended use of that product for heating purposes is not in doubt.

Having regard to the discretion which Member States have as to the measures and mechanisms to adopt in order to prevent tax avoidance and evasion connected with the sale of heating fuels and since a requirement to submit to the competent authorities a list of statements from purchasers is not manifestly disproportionate, it must be held that such a requirement is an appropriate measure to achieve such an objective and does not go beyond what is necessary to attain it.

Secondly, a provision of national law under which, in the event of failure to submit a list of statements from purchasers within the time limit, the excise duty applicable for motor fuels is automatically applied to heating fuels even if those fuels are used as such, runs counter to the general scheme and purpose of Directive 2003/96, based on the principle that energy products are taxed in accordance with their actual use. Furthermore, such an automatic application of the excise duty applicable to motor fuels in the case of non-compliance with the requirement to submit such a list infringes the principle of proportionality. The application of the rate of excise duty provided for motor fuels to the heating fuels because of the infringement of the requirement imposed by national law to submit a list of statements from purchasers within the time limits set, where it has been held that there was no doubt as to the intended use of those products, goes further than is necessary to prevent tax avoidance and evasion (see paras 25, 26, 33-35, 39, 42).

In its opinion, the CJEU emphasized that general principles of law, which include the principle of proportionality, form part of the EU legal order. They must accordingly be observed not only by the EU institutions but also by Member States in the exercise of the powers conferred on them by EU directives (see, to that effect, inter alia, judgments of 21 February 2008 in Netto Supermarkt, C-271/06, EU:C:2008:105, paragraph 18, and of 10 September 2009 in Plantanol, C-201/08, EU:C:2009:539, paragraph 43).

It follows that national rules, such as those at issue in the main proceedings, which are intended, inter alia, to transpose the provisions of Directive 2003/96 into the domestic legal order of the Member State concerned must be consistent with the principle of proportionality (paras 20 and 21 ).

In another verdict, C-588/10, of 26 January 2012 (Minister Finansów vs Kraft Foods Polska SA), the CJEU defined the limits of the freedom of EU Member States to determine the rights and duties of taxpayers on the example of the requirement to possess confirmation 
of receipt of a correcting invoice. In that ruling it indicated that the requirement that, in order to be entitled to reduce the taxable amount as set out in the initial invoice, the taxable person must be in possession of acknowledgment of receipt of a correcting invoice by the purchaser of the goods or services constitutes a condition for the purpose of Article 90(1) of the VAT Directive (para 42).

However, the principles of the neutrality of value added tax and proportionality do not, in principle, preclude such a requirement. However, where it is impossible or excessively difficult for the taxable person who is a supplier of goods or services to obtain such acknowledgment of receipt within a reasonable period of time, he cannot be denied the opportunity of establishing, by other means, before the national tax authorities of the Member State concerned, first, that he has taken all the steps necessary in the circumstances of the case to satisfy himself that the purchaser of the goods or services is in possession of the correcting invoice and is aware of it and, second, that the transaction in question was in fact carried out in accordance with the conditions set out in the correcting invoice. Copies of the correcting invoice and the reminder addressed to the purchaser of the goods or services to send acknowledgment of receipt and, as KFP submitted at the hearing without being contradicted on that point, proof of payment or the production of entries from the accounts which make it possible to identify the amount actually paid to the taxable person in connection with the transaction in question by the purchaser of the goods or services may serve that purpose (cf. paras 41, 42).

Analysis of this verdict demonstrates that the CJEU, in interpreting provisions concerning value added tax, frequently applies the principle of neutrality alongside the principle of proportionality, the former of which is supposed to prevent VAT from burdening an entrepreneur. Furthermore, the principle of proportionality prevents the national legislator from applying any "automatic" mechanisms to tighten up tax regulations.

In its verdict of 29 July 2010 in case C-188/09, Dyrektor Izby Skarbowej w Białymstoku vs Profaktor Kulesza, Frankowski, Jóźwiak, Orłowski sp.j., formerly Profaktor Kulesza, Frankowski, Trzaska sp.j., the CJEU took up the imposition of sanctions for failure to maintain a record of sales using a cash register. In this judgment it was indicated that the common system of value added tax, as defined in Article 2(1) and (2) of First Council Directive 67/227/EEC of 11 April 1967 on the harmonisation of legislation of Member States concerning turnover taxes and in Articles 2, 10(1) and (2) and 17(1) and (2) of Sixth Council Directive 77/388/EEC of 17 May 1977 on the harmonisation of the laws of the Member States relating to turnover taxes - Common system of value added tax: uniform basis of assessment, as amended by Council Directive 2004/7/EC of 20 January 2004, does not preclude a Member State from imposing a temporary restriction on the extent of the right of taxable persons who have not complied with a formal requirement to keep accounting records of their sales to deduct input tax paid, on condition that the sanction thus provided for complies with the principle of proportionality. In essence, because it aims at ensuring the proper collection of tax and prevention of tax, such an obligation is consistent with the measures that can be applied by Member States under Art. 22 (8) of the Sixth VAT Directive. In that context, by providing that, in cases where that accounting obligation is not complied with, the proportion of the VAT which the taxable person may deduct is reduced by $30 \%$, that measure must be regarded as constituting an 
administrative sanction, the deterrent effect of which is intended to ensure compliance with that obligation. However, it is a matter for the national court to determine whether the procedure for determining the amount of the sanction and the conditions under which the facts relied on by the tax authorities in order to apply that sanction are recorded, investigated and, as the case may be, adjudicated upon effectively render meaningless the right to deduct VAT, and thus do not undermine the principle that the tax burden must be neutral in relation to all economic activities. It must be observed in this connection that the rate of the amount withheld in the main proceedings, which is limited to $30 \%$ and thus preserves the greater part of the input tax paid, appears neither excessive nor inadequate for the purpose of ensuring that the sanction in question is deterrent and, therefore, effective. Moreover, such a reduction on the basis of the amount of tax paid by the taxable person is not manifestly without any link to the level of the economic activity of the person concerned. Furthermore, in so far as the purpose of that sanction is not to correct accounting errors but to prevent them, its flat-rate nature, resulting from the application of the fixed rate of $30 \%$, and, consequently, the lack of any correspondence between the amount of that sanction and the extent of any errors which may have been made by the taxable person cannot be taken into account in the assessment of whether that sanction is proportionate (cf. paras 27, 28, 34-37, 39).

The Court also held that national provisions imposing administrative sanctions that can be imposed on VAT taxpayers in the event of their failure to apply a cash register to record transactions and tax sums due are not "special measures for derogation" intended to prevent certain types of tax evasion or avoidance within the meaning of Article 27(1) of the Sixth VAT Directive. Such a measure thus cannot constitute a „special measure for derogation" under Art. 27(1) because it displays characteristics of measures encompassed by Art. 22(8) of the Sixth Directive, on grounds of which Member States may impose other obligations they see fit for the proper accounting and collection of tax and prevention of tax fraud (cf. paras 41-43).

It was also held that Article 33 of the Sixth VAT Directive does not preclude the maintenance of provisions such as those of Article 111(1) and (2) of the Polish 2004 Law on VAT, which provide for administrative sanction in the event it is held a taxpayer has not adhered to the obligation of using a cash register to record turnover and tax sums due (cf. para 49).

In its verdict of 26 March 2015 in C-499/13, Marian Manikowski przeciwko Dyrektor Izby Skarbowej w Gdańsku, the Court took up the issue of a court bailiff being considered a VAT payer arising from the sale of movables in the course of enforcement proceedings. In that ruling, the CJEU held that Articles 9, 193 and 199(1)(g) of the VAT Directive must be interpreted as not precluding a provision of national law, such as that at issue in the main proceedings, which, within the context of a sale of immovable property effected through enforcement, imposes on a person - namely the court enforcement officer who made the sale - obligations to calculate, collect and pay the VAT on the proceeds of that transaction within the prescribed time-limits. In essence, the national regulation is designed to avoid situations in which the taxpayer, owing to poor financial condition, violates the obligation to pay VAT; such regulations can ensure the proper collection of the tax and be subject to Art. 273 of Directive 2006/112. Furthermore, although it is true that 
those provisions provide, in essence, that the tax may be payable only by a taxable person carrying out a taxable supply of goods or, in certain circumstances, by the purchaser of the immovable property, the function of the court enforcement officer as the intermediary responsible for the collection of that tax does not fall within those provisions. In essence, because the obligation merely ensuring the collection of the amount of the tax and its payment to the tax authority on behalf of the taxable person by whom it is payable, within the prescribed time-limit. In that situation, the court enforcement officer's obligation is not a fiscal obligation, because that obligation still lies with the taxable person (cf. paras 38, 39, 41, 42, 45).

Furthermore, the Court ruled that the principle of proportionality must be interpreted as precluding a provision of national law, such as that at issue in the main proceedings, under which a court enforcement officer must be liable with his entire assets for the amount of VAT due on the proceeds of the sale of immovable property effected through enforcement where he does not discharge his obligation to collect and pay that tax, provided that the court enforcement officer concerned actually has all legal means to discharge that obligation, which is for the referring court to determine (cf. para 53).

The presented case law demonstrates that the Court of Justice of the European Union, in interpreting the provisions of tax law, takes into consideration the principle of proportionality, which is intended to protect the taxpayer in certain situations. This principle serves as a sort of safety valve to protect against overly restrictive legislation. However, in the absence of sanctions for failure to record turnover in a cash register and the recognition of a court enforcement officer, the test of infringement of the principle of proportionality was failed.

\section{The Principle of Proportionality in the Case Law of the Supreme Administrative Court}

The principle of proportionality, derived from normative acts, impacts the interpretation of legislation applied by administrative courts in Poland. With a view to the effectiveness of EU law, which is defended by the Court of Justice of the European Union, the Polish Supreme Administrative court frequently invokes the case law of the CJEU in tax matters.

In its verdict of 18 May 2017 (I FSK 1916), the SAC ruled that Art. 88 (3a)(4)(b) of the Value Added Tax Act of 11 March 2004 (VAT Act) (OJ L 2011, No. 177, item 1054 as amended), under which issued invoices, correcting invoices, or customs documents containing sums inconsistent with the real value of goods and/or services (false values) are not grounds for tax deductions - in respect of those items for which false values have been provided, the proper interpretation is, in the event the evidence gathered gives the tax authority the possibility of assessing the true value of the transaction for which an excessive figure has been given in the invoice - with a view to the principles of neutrality and proportionality - the right remains to deduct tax in the portion consistent with the true value of the transaction.

In its verdict of 24 May 2016 (I FSK 1625/14), the SAC took the position that the time limit on exercising the right to deduct VAT provided for by Art. 86 (13) of the VAT 
Act, apart from specified cases from 1 January 2014 in Art. 86 (13a) of the Act regarding reverse charge to the purchaser, does not violate the principles of neutrality, balance, effectiveness, and proportionality, and is not in and of itself capable of making it practically impossible or severely hindering the exercise of the right of the duly diligent taxpayer to take the deduction; instead, it constitutes a sort of sanction for an insufficiently diligent taxpayer in the form of the loss of the right to deduct that tax upon expiry of the time limit. The time limit can be waived only in the event a duly diligent taxpayer could not observe it owing to causes beyond his control.

In turn, in its verdict of 22 October 2015 (I FSK 1131/14), the SAC ruled that an invoice containing a formal defect that could be remedied by the issuance of a correcting note (e.g. address of the purchaser) allows the taxpayer under Art. 86 (1) of the VAT Act to exercise the right to deduct the tax listed in the invoice within the time limits provided for by the Act (Art. 86 [10] [1]; from 1 January 2014 Art. 86 [10] and [10b] [1]), regardless of whether the formal defects in the invoice are corrected - if there is no risk of fraud or abuse (the activities documented by the invoice were performed on behalf of the taxpayer and benefited his taxable activity). However, an invoice that has not been corrected and whose formal defect is so serious as to render it impossible to determine the true scope (subjective and/or objective) of the transactions listed in the invoice, and by the same token to determine whether they have in fact taken place, thereby giving rise to the possibility of fraud or abuse as well as preventing the effective collection of tax - does not give the taxpayer the right under Art. 86 (1) VAT Act to deduct the tax assessed from such an invoice. This does not constitute an infringement of the principles of neutrality and proportionality.

Invoking the principle of proportionality in its verdict of 21 October 2014 (I FSK $1536 / 13$ ), the SAC held that in the case of a taxpayer who - meeting all the conditions set out in Art. 89a (2) of the VAT Act as worded through 31 December 2012 - revised the tax due in an inappropriate accounting period, a correcting filing submitted pursuant to Art. $81 § 1$ of the Tax Code of 29 August 1997 (OJ L 2012, item 749 as amended) with the intent of correcting that defect and settling the adjusted tax due on the basis of Art. 89a (1) VAT Act in the proper accounting period indicated in Art. 89a (3) is not subject to the time limit imposed by Art. 89a (2) (5) VAT Act, as there has been no fraud or detriment to the state budget.

In another verdict of 9 May 2015 (I FSK 709/12), the SAC, invoking EU and Constitutional standards, indicated that interpretation of Art. 116 (6)(2) of the VAT Act cannot lead to violations of the principles of VAT neutrality, proportionality (as defined by Art. 31 [3] and Art. 2 of the Constitution of Poland and Art. 5 of the Treaty on European Union), and protection of property rights (as defined by Art. 21 [1] and Art. 64 [1] of the Constitution of Poland). This means that the provision in question should be interpreted as not depriving the taxpayer submitting past-due payment for agricultural products and/ or services to a farmer assessed lump-sum tax, encompassing lump-sum tax rebate, the right to recover the value of the tax.

In its verdict of 12 June 2012 (I FSK 841/11), the SAC held that depriving a taxpayerseller the right provided for in Art. 129 (1) of the VAT Act to apply the tax rate of $0 \%$ to the supply of goods transported outside the European Union, and on which that taxpayer 
refunded the tax to a traveller, for the sole reason that the taxpayer did not adhere to the informational conditions provided for by Art. 127 (4)(1 and 4) VAT Act, violates the principle of proportionality expressed in Art. 31 (3) and Art. 2 of the Constitution of Poland.

\section{Summary}

Initial research undertaken in the preparation of this work has demonstrated that the principle of proportionality plays an important role in the application of tax law in effect in the countries of the European Union. An important role in shaping the proper implementation of tax law is performed by the Court of Justice of the European Union. On the one hand, with the test of adherence to the principle of proportionality the CJEU examines whether a Member State has violated that principle. On the other hand, the Court, in settling disputes between a taxpayer and tax authorities, examines whether the applied measures are adequate to the circumstances. The Court's case law in this respect is diverse, as it ascertains infringement of the principle of proportionality through the introduction of specified solutions, but in the case of the imposition of sanctions and recognition of a court enforcement officer as a taxpayer it holds that the indicated principle has not been violated, by the same token providing certainty as to the law.

The Supreme Administrative Court, particularly in turnover taxes subject to harmonization - value added tax and excise tax - applies EU-friendly interpretation (consistent with EU law). In practically every judgment of the SAC, we may find references to the case law of the CJEU. Particular attention is paid by administrative courts in Poland to the application of the principle of proportionality when interpreting tax law. In this respect the SAC invokes not only EU standards, but also points to constitutional solutions in effect in Poland.

The rulings of the SAC within the subject matter being examined here are diversified and dependent on the circumstances of a particular case.

The research issue taken up concerning the principle of proportionality in tax law should be explored further. 